\title{
Penguatan Tata Lokasi Wisata Berbasis Syariah Sebagai Upaya Pengembangan Potensi Wisata Pulau Madura
}

\author{
Strengthening Sharia-Based Tourism Site System as an Effort to Develop Tourism Potential \\ of Madura Island
}

\author{
Ach Yasin ${ }^{1 *}$, Rachma Indrarini ${ }^{1}$, Moch Khoirul Anwar ${ }^{1}$, Hendry Cahyono ${ }^{1}$ \\ ${ }^{1}$ Universitas Negeri Surabaya \\ *ach.yasin@unesa.ac.id
}

\begin{abstract}
ABSTRAK
Pengabdian Kepada Masyarakat didasarkan pada kebutuhan dan keinginan warga Desa Rombiya Timur dan Desa Rombiya Barat, Ganding, Sumenep untuk mengembangkan potensi wisata di wilayahnya. Desa Rombiya Timur dan Desa Rombiya Barat merupakan salah satu desa di wilayah Ganding Sumenep yang memiliki potensi wisata yang melimpah. Salah satu wisata yang ada di kawasan ini adalah Tebing Grunggungan. Kawasan wisata, merupakan wisata baru yang pengelolaannya masih sederhana. Sehingga PKM ini lebih difungsikan untuk mengajarkan kepada masyarakat terkait strategi pengelolaan pariwisata. Sumenep merupakan kota religi yang sebagian besar penduduknya beragama Islam sehingga potensi wisata syariah memiliki peluang yang besar. Berdasarkan permasalahan tersebut kami menawarkan sosialisasi operasional wisata syariah serta pembuatan maket langkah wisata syariah di desa. Program ini bermanfaat bagi masyarakat sekitar, dalam jangka pendek masyarakat akan memiliki konsep terkait pengembangan pariwisata yang ada dan dalam jangka panjang diharapkan terjadi peningkatan pendapatan masyarakat dan peningkatan pertumbuhan ekonomi.
\end{abstract}

Kata kunci - Sumenep, Islamic Tourism

\begin{abstract}
Community Service is based on the needs and desires of the residents of East Rombiya Village and West Rombiya Village, Ganding, Sumenep to develop tourism potential in their area. The village of East Rombiya and Village of West Rombiya are one of the villages in the Ganding Sumenep region with abundant tourism potential. One of the tours in the region is the Grungungan cliff. The tourist area, is a new tourism whose management is still simple. So that this PKM is more functioned to teach the community related to tourism management strategies. Sumenep is a religious city, most of its population are Muslims so that the potential of Islamic tourism has a great opportunity. Based on these problems we offer socialization of sharia tourism operations as well as making sharia tourism place mockups in the village. This program will benefit the surrounding community, in the short term the community will have a concept related to the development of existing tourism and in the long run it is hoped that there will be an increase in community income and an increase in economic growth.
\end{abstract}

Keywords - Sumenep, Islamic Tourism 


\section{Pendahuluan}

Pariwisata merupakan salah satu penyumbang devisa terbesar di Indonesia. Setiap daerah berlomba - lomba untuk mengembangkan pariwisata yang dimiliki. Berbagai macam konsep wisata baik wisata alam, ziarah, wisata buatan serta tata cara pemasaran digunakan untuk menarik wisatawan datang. Tujuan utamanya adalah untuk meningkatkan pertumbuhan ekonomi.

Selain itu kemajuan sektor pariwisata seringkali dikaitkan dengan stabilitas ekonomi dan keamanan yang baik. Semakin maju pariwisata di suatu daerah maka perekonomian akan cenderung stabil dan pendapatan masyarakat tinggi. Disisi keamanan, semakin maju pariwisata maka kondisi keamanan akan cenderung stabil. Hal tersebut dapat terjadi karena pemerintah mengupayakan kondisi keamanan yang stabil agar wisatawan dapat percaya dan nyaman berwisata di daerah tersebut.

Salah satu wilayah di Indonesia yang memiliki potensi wisata besar adalah Jawa Timur. Potensi wisata yang ada tidak hanya datang dari dalam negeri namun juga luar negeri. Berikut adalah data perkembangan kunjungan wisatawan mancanegara ke Provinsi Jawa Timur tahun 2007 sampai dengan 2017. Dari grafik tersebut dapat terlihat adanya peningkatan kunjungan wisatawan di Jawa Timur setiap tahunnya. Dapat diartikan, Jawa Timur merupakan salah satu daerah dengan potensi wisata.

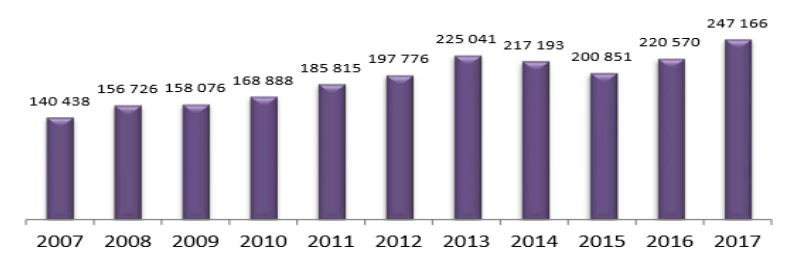

Sumber : BPS Prov. Jatim;’2018

Gambar 1. Grafik Perkembangan Kunjungan Wisatawan Mancanegara ke Provinsi Jawa Timur, 2007-201

Jawa timur memiliki beberapa wisata unggulan di setiap daerah. Probolinggo memiliki wisata gunung Bromo, Banyuwangi memiliki wisata grean beach, Lumajang memiliki wisata kawah gunung ijen dan pulau Madura memiliki potensi wisata unggulan yang dapat dikembangkan.

Sumenep merupakan salah satu kabupaten di pulau Madura. Pulau gili labak, pulau Gili Iyang yang terkenal akan oksigennya, serta beberapa budaya merupakan potensi wisata yang dimiliki oleh Sumenep. Akan tetapi terdapat satu daerah di selatan Sumenep yang memiliki potensi wisata yang luar biasa namun belum dikelola dengan baik. Desa Rombiya Timur dan Desa Rombiya Barat, memiliki potensi wisata yang besar seperti tebing grunggungan dan rumah tradisional. Akan tetapi wisata tersebut baru dikelola secara tradisional oleh warga. Berikut adalah lokasi desa wisata rombiya timur.

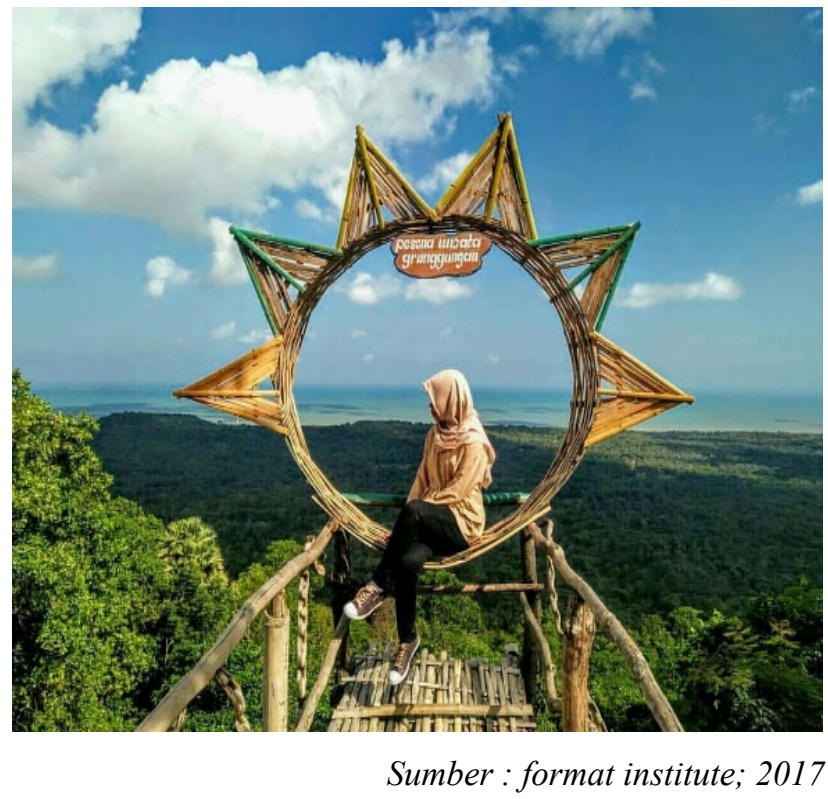

Gambar 2. Tebing Grunggungan Rombiya Timur

Bukan hanya terkait dengan pengelolaan yang masih tradisional, namun konsep dan tata kelola tempat wisata masih menjadi permasalahan utama di desa ini. Meskipun terdapat seni, budaya dan kuliner yang dapat menambah minat wisatawan untuk berkunjung ke rombia barat dan rombia timur seperti halnya budaya pencak silat, rumah adat, kuliner gula aren dan legen.

Sumenep merupakan Kabupaten religius. Sebagian besar penduduk merupakan umat muslim dan di setiap wilayah di Sumenep memiliki pondok pesantren. Hal tersebut membuat Sumenep memiliki potensi terkait 
dengan wisata syariah. Pariwisata syariah merupakan konsep pariwisata yang menyediakan layanan berlibur dengan fasilitas yang lengkap untuk kebutuhan seorang muslim. Muslim memiliki etika hidup yang diatur dalam syariat termasuk di dalamnya makanan dan minuman halal, obat dan kosmetik, fashion dan juga wisata (Sofyan: 2012), sehingga wisata syariah tidak hanya diartikan pada wisata ziarah kubur namun wisata syariah juga dapat berupa wisata alam, wisata budaya, wisata buatan yang dinaungi nilai - nilai Islam. Menurut kementerian pariwisata dan ekonomi kreatif serta BPH DSN MUI, wisata syariah memiliki kriteria umum yakni berorientasi pada kemaslahatan umum, berorientasi pada pencerahan, penyegaran dan ketenangan, menghindari kemusyrikan dan khurafat, menghindari maksiat, menjaga perilaku, etika dan nilai luhur kemanusiaan, menjaga amanah, keamanan dan kenyamanan, bersifat universal dan inklusif, menjaga kelestarian lingkungan, dan menghormati nilai nilai sosial budaya dan kearifan lokal.

Berdasarkan permasalahan dan potensi yang ada maka disepakati bahwa masalah yang dihadapi oleh desa rombia timur dan rombia barat adalah:

a. Kurangnya penguatan tata lokasi dari wisata di desa rombia timur dan rombia barat

b. Konsep wisata berbasis syariah yang akan diterapkan pada desa rombia timur dan rombia barat.

Dengan adanya PKM yang membahas terkait hal tersebut, diharapkan dapat mengembangkan potensi wisata yang ada di kabupaten Sumenep.

\section{Target dan Luaran}

Target dalam Pengadilan Kepada Masyarakat ini adalah perangkat desa, karang taruna dan pengelola wisata desa rombia barat dan rombia timur. Dalam kegiatan sosialisasi ini target peserta sebanyak 30 orang.

Tujuan dari kegiatan ini adalah untuk mengembangkan potensi wisata desa rombia timur dan rombia barat. Pengembangan berupa penguatan tata lokasi yang dituangkan dalam maket pace berupa konsep desa wisata. Selain itu konsep desa wisata didasarkan pada syariat Islam sehingga kedepannya menjadikan desa rombia barat dan rombia timur sebagai desa wisata berbasis syariah.

\section{Metodologi}

Langkah - langkah yang dilaksanakan untuk mengatasi permasalahan yang dihadapi oleh mitra dapat dijelaskan sebagai berikut

\section{1. lokasi}

Survei lokasi ini dilaksanakan sebelum pembuatan proposal PKM. Survei ini laksanakan oleh perwakilan dari tim. Hasil survey digunakan dalam identifikasi permasalahan mitra.

\subsection{Identifikasi permasalahan}

Identifikasi permasalahan ini merupakan hasil wawancara kebutuhan mitra (masyarakat desa rombia timur dan rombia barat) serta hasil analisis situasi dari wilayah desa. Dari hasil identifikasi ini disimpulkan dua masalah utama yang akan diselesaikan yakni penguatan tata lokasi dan penguatan konsep wisata berbasis syariah.

\subsection{Sosialisasi pariwisata syariah}

Sosialisasi ini merupakan pengetahuan dasar terkait dengan prinsip wisata berbasis syariah. Tujuan dari sosialisasi ini adalah dalam jangka panjang wilayah desa dapat membangun dan mengembangkan wisata berbasis syariah.

3.4. FGD pembuatan maket pace dalam upaya penguatan potensi wisata di Pulau Madura.

Pembuatan maket pace ini tidak dibuat secara langsung, namun dibuat oleh tim dengan dasar FGD yang dilakukan antara tim dengan masyarakat terkait konsep pariwisata.

Peran mitra dalam pelaksanaan program meliputi penyediaan SDM yang akan mengikuti pelatihan dan pendampingan, tempat untuk kegiatan pelaksanaan program. Motivasi dan komitmen yang tinggi untuk maju menjadi modal bagi pelaksanaan dan keberlanjutan program.

Evaluasi pelaksanaan kegiatan pengabdian kepada masyarakat dilaksanakan dengan melihat ketercapaian indikator yang telah ditetapkan. Evaluasi keberlanjutan program dilakukan untuk 
memantau apakah program masih berjalan setelah kegiatan pengabdian selesai dilaksanakan. Pemantauan dilakukan dengan tetap melakukan pendampingan kepada mitra meskipun kegiatan pengabdian telah selesai. Tim pengabdian masih tetap memberikan layanan konsultasi dan diskusi dengan mitra. Melalui cara tersebut evaluasi keberlanjutan program dapat dilaksanakan dan dipantau.

\section{Pembahasan}

Pelaksanaan Pengabdian Kepada Masyarakat berjalan sesuai dengan harapan. Kegiatan telah dilaksanakan adalah sebagai berikut :

\subsection{Survei lokasi}

Survei lokasi dilaksanakan oleh perwakilan dari tim PKM. Dalam survey lokasi ini ditemukan dua buah tempat wisata yang menjadi potensi pengembangan. Pertama adalah bukit grunggungan. Akses untuk menuju bukit ini cukup sulit, dimana jalan hanya dapat dilalui oleh satu mobil dan tidak tersedianya lahan parkir untuk mobil. Sehingga perlu adanya solusi terkait dengan hal tersebut. Kedua adalah wisata rumah tradisional, rumah ini merupakan rumah budaya yang struktur bangunannya masih bersifat tradisional sehingga menjadi potensi untuk dikembangkan.

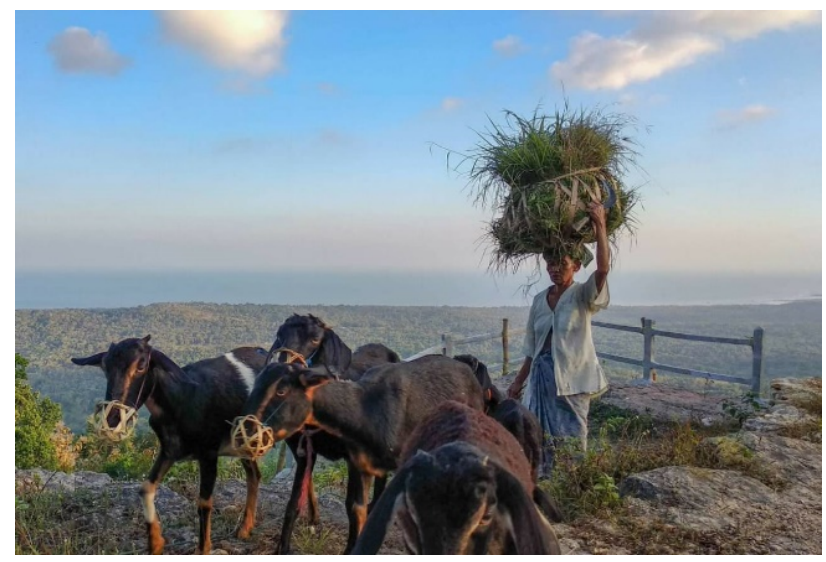

Sumber : hasil survey, 2019

Gambar 3. Bukit Grungungan

\subsection{Identifikasi permasalahan}

Identifikasi permasalahan dilaksanakan setelah dilaksanakan survey. Dari hasil survey diketahui terdapat dua objek wisata yang dapat dikembangkan kembali. Dari hasil identifikasi fokus permasalahan yakni :

a. Penguatan tata lokasi yang tertuang dalam maket pace wisata

b. Penguatan konsep wisata berbasis syariah

\subsection{Sosialisasi pariwisata syariah}

Kegiatan ini dilaksanakan pada tanggal 27 Juli 2019 di balai desa rombia barat Kecamatan Ganding Kabupaten Sumenep. Jumlah peserta hadir adalah sebanyak 40 orang. Peserta yang hadir cukup antusias dengan banyaknya peserta yang memberikan pertanyaan serta gagasan terkait dengan konsep wisata syariah. Pemateri dalam sosialisasi ini adalah Ach. Yasin.

Sosialisasi wisata syariah dilaksanakan selama satu jam, dengan materi dasar wisata syariah, ketentuan terkait wisata syariah, fasilitas yang wajib ada pada wisata syariah dan lain sebagainya. Dasar dari wisata syariah adalah berpegang teguh pada prinsip-prinsip syariah dengan menghindarkan diri dari syirik, maksiat, munkar, dan kerusakan (fasad); menjaga kewajiban ibadah selama berwisata; menjaga akhlak mulia; menghindari destinasi wisata yang bertentangan dengan prinsip-prinsip syariah.

Pada sosialisasi ini mitra digiring untuk mengembangkan potensi wisatanya berbasis syariah dengan dua acara yakni :

a. Pengadaan fasilitas ibadah yang layak pakai, mudah dijangkau dan memenuhi persyaratan syariah (tempat bersuci, dan tempat untuk melaksanakan ibadah)

b. Menjual makanan dan minuman halal yang terjamin kehalalannya.

Dengan adanya minimal 2 hal tersebut maka wisata baru berbasis syariah akan tumbuh dan dalam jangka panjang akan memberikan dampak positif bagi masyarakat sekitar.

\subsection{FGD pembuatan maket pace}

FGD pembuatan maket pace ini dilaksanakan oleh tim dan mitra. Tim dan mitra berdiskusi untuk membuat suatu konsep tata lokasi dan design wisata syariah. Pada tahap ini antara mitra dan tim membuat konsep tata lokasi yang berkelanjutan dimana ketika wisatawan masuk ke Kecamatan Ganding, wisatatawan diberikan banyak pengalaman tidak hanya 
melihat keindahan Kabupaten Sumenep dari atas tebing namun juga menikmati seni dan budaya dari kecamatan ganding. Berikut adalah maket pace terkait dengan penguatan tata lokasi wisata.

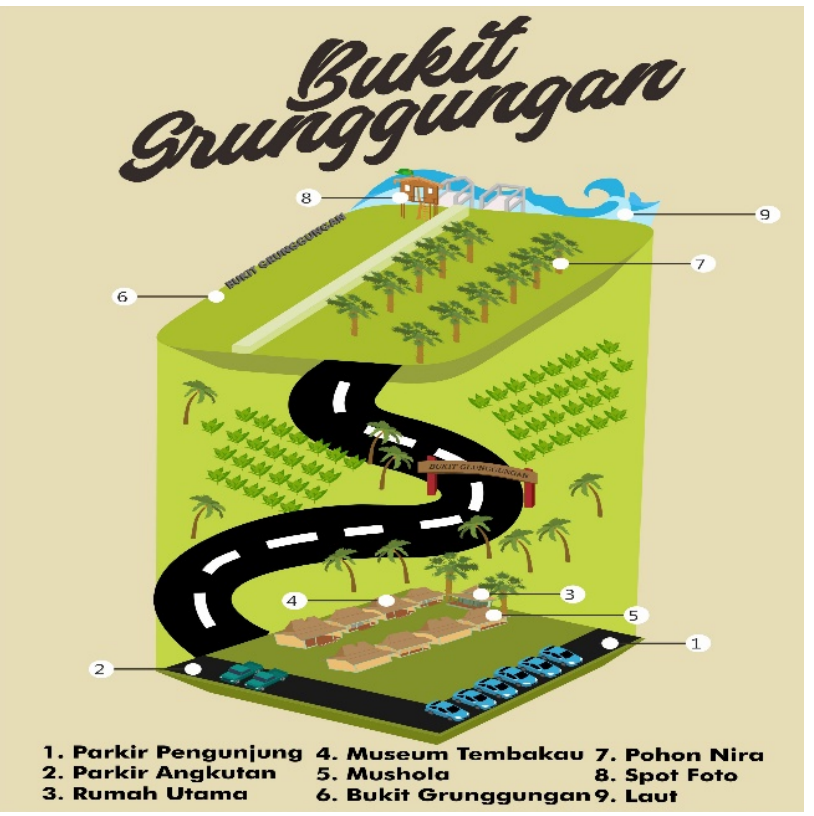

Sumber : hasil survey, 2019

b. Penguatan konsep wisata syariah dapat dihadirkan dengan adanya fasilitas ibadah dan penjualan makanan dan minuman yang halal.

\section{Daftar Pustaka}

[1] Ala-Hamarrneh, A. and Steiner, C.,2004, Islamic tourism: Rethinking the strategies of tourism development in the Arab worl after September 11, 2011. Comperative Studies of South east, 24(1), 173182.

[2] Arifin, M. Salim. 2009. Pariwisata Dalam Perspektif Islam. Jurnal Kepariwisataan Volume 01 No 2 Februari 2009, Akademmi Pariwisata Makasar.

[3] Hamzah, Amran. 2012. Exploring the Issues Associated With the Development, Management and Promotion of Islamic Tourism, University Teknologi Malaysia.

[4] Sofyan. Riyanto. 2012. Prospek Bisnis Pariwisata syariah. Jakarta: Buku Republika.

[5] Shani. M.A. Rivera and D. Severt. 2007. To bring god's word to all people: the case of a religious theme-site. Tourism: An international interdisciplinary journal. 55(1):39-50

Berdasarkan maket place di atas, ketika wisatawan masuk akan diarahkan di rumah tradisional. Lokasi rumah tua memiliki beberapa fasilitas yakni lahan parkir, kendaraan khusus untuk ke bukit grunggungan, museum tembakau, museum nira, mushola, tempat istirahat, pusat oleh - oleh dan tempat pertunjukan seni. Setelah kendaraan terparkir di rumah tua, wisatawan dengan menggunakan angkutan desa akan diantarkan ke bukit grunggungan. Dengan adanya penguatan tata lokasi ini diharapkan potensi wisata di pulau Madura semakin berkembang

\section{Kesimpulan}

Berdasarkan hasil pelaksanaan kegiatan program Pengabdian Masyarakat dapat disimpulkan bahwa:

a. Penguatan tata lokasi wisata berbasis syariah dapat dirancang dengan maket pace dimana konsep wisata berkelanjutan. Pengunjung tidak hanya disuguhkan wisata alam namun juga wisata budaya, seni dan kuliner. 